\title{
Explaining the Opportunities and Challenges of the Law on Dissemination and Free Access to Information in Iran from the Perspective of Lawyers
}

\section{Explicar las oportunidades y los desafíos de la Ley de difusión y libre acceso a la información en Irán desde la perspectiva de los abogados}

\author{
Mohaddeseh Yaghobi \\ Department of Communication Sciences, Ardabil Branch, Islamic Azad University, \\ Ardabil, Iran \\ ORCID ID: https://orcid.org/0000-0003-4828-077X
}

Mohammad Soltanifar

Department of Communication Sciences, Science and Research Branch, Islamic Azad

University, Tehran, Iran

ORCID ID: https://orcid.org/0000-0002-7530-2711

\begin{abstract}
Ali Jafari
Department of Communication Sciences, Ardabil Branch, Islamic Azad University, Ardabil, Iran

ORCID ID: https://orcid.org/0000-0001-9204-8105

Jafar Salmanzadeh

Department of Law and Political Science, Mohaghegh Ardabili University, Ardabil, Iran

ORCID ID: https://orcid.org/0000-0001-7270-7863
\end{abstract}

Received 09-08-20 Revised 10-10-20

*Correspondence

Email: Soltanifarm2@gmail.com
Accepted 12-20-20 On line 03-08-21

Cite as:

Yaghobi, M., Soltanifar, M., Jafari, A., \& Salmanzadeh, J. (2021). Explaining the Opportunities and Challenges of the Law on Dissemination and Free Access to Information in Iran from the Perspective of Lawyers. Propósitos $y$ Representaciones, 9 (SPE3), e1113. Doi: http://dx.doi.org.10.20511.pyr2021.v9nSPE2.1113 


\section{Summary}

The right to have free access to information is one of the most underlying examples of the first generation of human rights. Also, it is a requirement of realization of citizenship rights and one of the vital issues in the principle of democratic participation discourse. Due to the importance of this issue, the approval of the Law on Dissemination and Free Access to Information in 2009 in Iran can be a vital step toward the achievement of free access to information, transparency, and favorable democracy. The purpose of this study is to explain the challenges and opportunities of the Law on Dissemination and Free Access to Information in Iran. Hence, by referring to scholars in the field of law, formal and natural evaluation of Law on Dissemination and Free Access to Information was done. The method in this study is data-based, and deep interviews are used to analyze the different aspects of this issue. The statistical population in this study consists of scholars and experts of the law. The results obtained from the interviews led to the identification of three opportunities including good democracy and governance, prevention and fight against corruption and revival and implementation of the citizenship document. Besides, five vital challenges were identified in the section of interviewing with lawyers: the ambiguity of law exceptions, lack of sanction of law, ambiguity in the concept of access to information, the challenge of dissemination system and access to information, and parallel laws challenges. According to the identified challenges and opportunities, it seems that the efforts of Ministries of Culture and Arts, Communications and Technology, Education, and National Media, and revision of legal articles concerning these challenges can be the proper solution to these problems.

Keywords: freedom of information, Law on Dissemination and Free Access to Information, legal challenges of Law on Dissemination and Free Access to Information, legal opportunities of Law on Dissemination and Free Access to Information.

\section{Resumen}

El derecho a tener libre acceso a la información es uno de los ejemplos más subyacentes de la primera generación de derechos humanos. Además, es un requisito de la realización de los derechos ciudadanos y uno de los temas vitales en el discurso del principio de participación democrática. Por la importancia de este tema, la aprobación de la Ley de Difusión y Libre Acceso a la Información en 2009 en Irán puede ser un paso vital hacia el logro del libre acceso a la información, transparencia y democracia favorable. El propósito de este estudio es explicar los desafíos y oportunidades de la Ley de Difusión y Libre Acceso a la Información en Irán. De ahí que, al referirse a académicos en el campo del derecho, se realizó una evaluación formal y natural de la Ley de Difusión y Libre Acceso a la Información. El método de este estudio se basa en datos y se utilizan entrevistas profundas para analizar los diferentes aspectos de este tema. La población estadística de este estudio está formada por académicos y expertos en derecho. Los resultados obtenidos de las entrevistas permitieron identificar tres oportunidades que incluyen la buena democracia y gobernabilidad, la prevención y lucha contra la corrupción y la reactivación e implementación del documento de ciudadanía. Además, se identificaron cinco desafíos vitales en la sección de entrevistas con abogados: la ambigüedad de las excepciones a la ley, la falta de sanción de la ley, la ambigüedad en el concepto de acceso a la información, el desafío del sistema de difusión y acceso a la información, y desafíos de leyes paralelas. . De acuerdo con los desafíos y oportunidades identificados, parece que los esfuerzos de los Ministerios de Cultura y Arte, Comunicaciones y Tecnología, Educación y Medios de Comunicación Nacional, y la revisión de artículos legales sobre estos desafíos pueden ser la solución adecuada a estos problemas.

Palabras clave: libertad de información, Ley de Difusión y Libre Acceso a la Información, impugnaciones legales de la Ley de Difusión y Libre Acceso a la Información, oportunidades legales de la Ley de Difusión y Libre Acceso a la Información

\section{Introduction}


The right to know is one of the citizenship rights with wide dimensions. Access to the right information on the domestic and international issues and media freedoms, dissemination, the establishment of dissemination institute, prohibition of censorship, trying to provide impartiality and health of media, and making exact regulations on mass media such as radio and TV are the public rights to use information in a democratic system (Naderi, 2011: 1).

Taking benefit of freedom of expression, and access to information are first-generation human rights. Using the first generation rights needs lack of observance of government in the process of these laws and freedoms on one hand, and its obligation in respecting them and encountering violators on the other hand (Hashemi, 2012: 146). The more the quality and quantity of the access of citizens to information are increased, the more the quality of pervasive and cooperative democracy would be increased. Free access to information and regulations caused by that need the realization of citizenship laws and can be one of the main issues of democratic discourse.

Free access to information as a fundamental knowledge needs ethical commitment to search realities with no orientation and dissemination of knowledge with no bad will. Perception and cooperation among the nations are dependent on freedom of information (Mohseni, 2005: 11).

The right to free access to information as a fundamental human right was recognized for the first time in the 1946 United Nations General Assembly Resolution 59 and became the bedrock of all types of liberty. This right had been emphasized explicitly in article 19 of the United Nations Declaration of Human Rights of 1948, and the United Nations International Covenant on Civil and Political Rights of 1966. Although much time has passed from the time that the issue of freedom of information was emphasized for the first time in the world and Sweden approved the Law of Freedom based on the fundamental concept of "freedom of information"; Iran approved the Law on Dissemination and Free Access to Information in 2009 after many ups and downs and despite the disputes after four years of research and discussion (Sedghi, 2013: 9). Codification of the executive regulations of this law lasted till 2015, and finally guaranteed the right of citizens to have free access to free information in five chapters and 23 articles. Hence, an institute was established to control the performance of this law under the title of Commission for Dissemination and Free Access to Information (Vijeh and Taheri, 2011: 243-244), chaired by the Minister of Culture and Islamic Guidance.

In legal terms, in a democratic society, the claim is that the government with all pillars and all information in it belongs to the people, and the governors are responsible to handle that on behalf of the people. Hence, every owner has the right to have access to personal property. People as the real and initial owners of the government and the information in it have the right to have free access to information and state documents. On this basis, only people can restrict their access to the information, and this can be done by law as a democratic institute (Ghaderi, 2010: 22). Although about one decade has passed since the approval of this law, the mechanisms to enforce this law have not been provided competently. Also, there are still weaknesses and dark points in the definitions and concepts of this law, and the expectations of the legislator and the purposes are not realized yet.

Hence, according to the importance of the issue, this study has analyzed the challenges and opportunities of this law in current situations of Iranian society, and the formal and structural principles dominated the Law on Free Access to Information according to lawyers. Also, the study has provided solutions and suggestions to enforce the law and to accept that.

\section{Methodology}

The method in this study is qualitative, and this is applied research in terms of research type. In terms of the data collection method, this is a descriptive-exploratory study. As this study tends to identify and determine the challenges and opportunities of the Law on Dissemination and Free Access to Information, and there is no literature in this field, this can be exploratory research using a qualitative method. Besides, instead of presenting the hypotheses or proving them, the study answers the research questions. The data collection is done using a deep interview with the lawyers. The interview questions are provided based on research questions and purposes. To identify the experts for an interview, purposeful sampling was used, and was continued until reaching the saturation point; where the new data is not different from the previously collected 
data (Rezayan Ghiyebashi and Bayati, 2018: 18). In the first step, the interview was done with 8 individuals. From sample 7 onwards, no new information was obtained; although interviews were continued with 10 individuals and were then ended.

According to the research objectives, data analysis and coding were done based on data-based theory.

\section{Results}

In this study, after deriving and implementing the text of interviews, generalities of Law on Dissemination and Free Access to Information emphasized in interviews were presented. The results, after passing through the filter of the method, were presented in two headings of opportunities and challenges to the Law on Dissemination and Free Access to Information. In the first section, the opportunities of Law on Dissemination and Free Access to Information were derived and categorized according to the scholars. In the second section, the challenges of Law on Dissemination and Free Access to Information obtained from a deep interview with the experts and lawyers were analyzed, classified, and categorized. The analyses showed that although there are different and even conflicting attitudes among the scholars, there is relative convergence in the answers. At the end of this section, the theoretical model of research obtained from the common and different points of scholars of communications and media was presented.

Opportunities

The most underlying effects of transparency and opportunities emphasized by the experts are: Proper democracy and governance

Transparency is one of the fundamental conditions for the orientation of the will of individuals, and the will plays a vital role to create a democratic society. The basis of transparency emphasizes the theories of consultative democracy, which believe that transparency should include a wide range of mechanisms enabling the participation of citizens in policy-making through have effective access to the procedures and the consequences of the processes. Transparency as one of the vital elements of proper governance is important because it is impossible to gain public trust in the ruling system without it. Transparency and avoiding privacy culture is the required condition to gain public trust in the ruling system and the way of governance. To make people active in the field of governance, they should have access to high-quality information. This can be achieved by documentary transparency, and this is exactly one of the challenges to this law in Iran. Transparency of the governmental activities is an inseparable situation from good governance and active participation of citizens; although many organizations such as IRIB, Police, Organization of Forensic Documents and Property, and Prison Affairs Organizations still have not become a member of this system. They refuse to disseminate the information or refuse to provide sufficient information for the citizens.

\section{Prevention and fight against corruption}

The second opportunity of the Law on Dissemination and Free Access to Information is prevention and fight against corruption. Corruption (administrative corruption) can be defined as a public opportunity to achieve personal interest. Explicit examples of corruption include abuse of administrative position, or violation of regulations to gain personal interest, appointing relatives, bribery, money laundering, misappropriation of unknown assets, control of property by relatives, hiding illegitimate properties, encouraging people to take such measures, and buying votes (Ansari, 2008: 38). Therefore, the most traditional cause of needing transparency is prevention and fighting against corruption. In this way, the Parliamentary Research Center has mentioned in the expert commenting on Freedom of Information Bill that the most underlying purpose is fighting against corruption. The report says: "the most important purpose of the Law on Freedom of Information is fighting against rooted corruption in Iran by the transparency of governmental affairs. In case of inaccurate enforcement of the law, it may lead to the wide extension of the corruption". 


\section{Revival and implementation of the citizenship document}

One of the social, political, and legal components of the modern government in the contemporary world is the position and the rights of the citizens. Following the social evolutions and political revolutions over the past two centuries and collapse of the foundation of authoritarian governments, and the advent of new concepts in the political and legal literature, a new course was switched in the historical experience of humans. The establishment of legislation parliaments, separation of governmental powers, dependence in the judiciary, restriction of political power, and the emergence of constitutions as a public covenant between the political sovereignty and citizens could create a new horizon in regulation and transparency of interactions of the government and citizens, and the rights of citizens in constitutions on new governments. Citizenship rights refer to a series of rights and freedoms, the enforcement of which is guaranteed by the government. The content of these rights may vary from one state to another.

The Iranian citizens should have free access to all regulations or the decisions of public institutes in the field of executive power on the dignity of their life in the limit of the law, and if it is not against national security. No one can avoid them having free access to information and the laws creating their rights and obligations. Every citizen, in the widest form and limit of legal exceptions, has the right to have access to his/her records and information in public and private organizations directly or indirectly using public financial bonuses and can be informed of the decisions made on him/her by the public institutes. All citizens have the right to have a print of said information, records, and decisions.

\section{Challenges}

The most underlying challenges emphasized by scholars after passing through the method include:

\section{The ambiguity of exceptions of Law on Dissemination and Free Access to Information}

According to a general principle, the limitation to have free access to public information is an exception, and the state systems should reject the demand of citizens to have access to the information based on law and acceptable causes. Therefore, the exceptions of free access to information should be predicted in law carefully. To restrict the right to have access to information, it should have three general characteristics: the information asked should be in a certain relationship with the legal purpose mentioned by law; disclosure of information causes serious damage to the referred purpose, and the damage is more than the public interest of access to information. It should be mentioned that no one of the public systems and institutes should be an exception in terms of freedom of information, even if the majority of their functions are within the limit of the exceptions. This is true for all public departments (legislative, executive, and judicial power), and all public functions (security and defense systems).

Chapter 4 belongs to the exceptions of access to information. In the field of these exceptions, public secrets, protection of privacy, protection of health and business information, and national security are mentioned. In article 17 of the Law on Dissemination and Free Access to Information, same as other human rights, the limitations on the right to have access to information are counted. In most cases, limitations counted on human rights use general titles, and it is difficult to identify their example based on the taste of the authorities, which can be a barrier to the realization of said rights. Whereby article 17 of this law, if the requested information damages the public order or security and this is authenticated for the institutes, they should refrain from providing information. These are general titles and determining their examples is undoubtedly hard to do. This is because; no impartial institute is established to handle the disputes of the applicant and the desired institute to prevent the institute from avoiding providing information by excusing the titles such as public security and peace. It seems that other regulations should be approved, along with the Law on Dissemination and Free access to Information, so that this law can achieve desired goals. Also, public secrets and privacy should be defined on the other hand.

\section{Lack of legal sanctions and secrecy culture}

The proportionality principle between crime and punishment is one of the dominant principles on the punishments, which is not observed in the studied law. One of the transparent forms of the 
manifestation of justice in criminal law is providing proportionality between the crime and punishment, which has been changed into a principle in criminal legal systems. In general, observance of the proportionality principle never means retaliation, because ethical restriction prevents that, but also proportionality means equality in the effect and value of crime and punishment on the criminal and the society. According to the orientation of the criminal and the society in providing proportionality, two major schools of punishment and utilitarianism are created. The early one emphasizes the proportionality of criminal and the crime, and the latter one emphasizes the preventive advantage of punishment. The necessity of strong criminal protection of the law is one of the most fundamental principles, which is suitable leverage to enforce the Law on Dissemination and Free Access to Information. Now, the question is that what we should do if the dissemination and free access to information are done against the regulations in this law? It should be claimed that prevention of turnover by a public institute can be a barrier to the commission. Although article 22 regards the individuals committing these measures as criminals and has convicted them to pay a fine, the ambiguity remains that is it possible to punish a public system as a legal entity or not? Whether it is possible to appoint a fine for a public institute or legal entities causing prevention of sending report should be punished? Another objection to this section may be this issue that no case is predicted on the offense of Commission on Dissemination and Free Access to Information.

\section{Ambiguity in the concept of access to information}

Some key concepts of the studied law are ambiguous. The first ambiguity is in the title of the law. There are some ambiguities in this title: first, the adjective "free" is not cleared in terms of meaning. Whether the adjective should be mentioned due to the purpose of the legislator and legal framework considered applying this right or not? Second, a general concept of "information" is considered in the title, which brings the ambiguity that whether it is absolute desired information or not? The assumption is rejected due to the context of law, and the title is not matched with the provisions of law. It seems that the term "public" should be used for "information" instead of the term "free" for dissemination.

Another ambiguous concept in this law is the term "information". On the term "information", a cognitive word difference in the law on access to information is observed: access to information against access to governmental records and documents. Information is an abstract word and general concept; although a document is an objective word and special concept. The realization of efficiency of freedom of information is dependent on using the widest meaning possible for the word if a term other than "information" is used. The ambiguities can be observed in other articles too. Whereby article 8 of the studied law, the public or private institute has to respond to the application of access to information as soon as possible. The question is that whether the aim of information in this section is public information or not? Whether general information is available for the public institutes or not? As article 2 says that every Iranian person has the right to have free access to general information, one can find out from article 8 that the aim of the information is general information. It should be noted that the philosophy of considering the right to access information is the elimination of the secure margin of public institutes on general information, which seems not true for the private institutes. Particularly, due to the definition presented in article 1, the range of public institutes is wider than private ones.

\section{Relevant and parallel regulations with Law on Dissemination and Free Access to Information}

There are some regulations in Iran, which conflict with the Law on Dissemination and Free Access to Information. In this law, chapter 4 has mentioned exceptions for the dissemination and free access to information. Article 13 in chapter 4 says: "if the applicant request is relevant to classified documents (public secrets), the public institutes shall refuse to provide the information. Access to classified information shall follow special regulations". Note "d" of article 1 in the Executive Bill of this law on the definition of legal terms says: "classified information or public secrets include secret and private documents subject to the Law on Punishment of Dissemination and Disclosure of Secret Public Documents approved in 1974, and the bill approved in 1975". Now, the study shall refer to the version of law approved in 42 years ago, to see that what does 
mean public document. Article 1 of the law says: "public documents refer to any kind of text or recorded information relevant to the obligations and activities of the ministries and public institutes affiliated to the government and public companies including letters, notebooks, records, photos, maps, stereotypes, graphs, films, microfilms, and recording tapes provided in the said institutes". The note of this article says: "the secret public documents are those, the disclosure of which is against the interests of the government or the nation", and "the secret public documents are those, the disclosure of which is against the special interests of the organization said in the article". Now, in the executive bill of the said law, article 1 tries to provide more careful definition of the documents. The article says: "secret public documents can be classified in four groups due to the credit of the care used to protect them. The first-class documents are specified under the title of totally secret documents, the second class ones are known as secret documents, third class is known as very secret, and the fourth class ones are known as confidential secret documents". However, the main problem of the bill is with articles 2 and 3, which specify that how a document is identified as public or public secret document. Article 2 says: "the class of each document is determined based on the provisions in it". More importantly, article 3 says: "the class of each document is determined by the officials of the department providing that. If the officer believes that the document is a secret, then the agreement of the chairman shall be gained". Hence, every public authority can specify that and the ordinary document is a public secret document, and prevent free access of people to that. Now, what can be the solution to this problem? The first solution is that article 18 of the executive bill has predicted a commission to solve the disputes in this field. Article 18 says: "to protect freedom of access to information, and public access to the information in public and private institutes providing public services, the authorities shall appoint required executive plans in the field of informing people, supervising the good execution, solving the disputes on the way of providing information subject to this law by providing unity of procedure, culture-making, guidance, and providing consultative theories. In this way, the commission of dissemination and free access to information shall be established following the order of the president by eight people". However, the amendments shall be done on the version of law approved in 1974, which made the problems. The public authorities shall make amendments to the said version of law to enforce the provisions of this act in the best way. Also, the officials shall establish such a commission to identify the secret and confidential documents.

\section{Conclusion}

The Law on Dissemination and Free Access to Information, same as other regulations, shall follow conditions in terms of form and structure so that the citizens can have easy and free access to the documents and information in public institutes. If the law on freedom of information is unable to provide favorable conditions formally for the access of citizens, handling the request, the objections, and the hearing procedure of administrative offense in this field, or the structure of providing information for citizens is not favorable, the right to access can't be fulfilled. Before this, there has been no law under the title of freedom of information, and the just constitution of Iran has referred to the right of citizens to have access to information in the field of rights of the nation.

The situation of the law and approval of executive regulations are required but not sufficient to protect freedom of information. For efficient protection of such rights, the preparations and commitment to the instruments are essential. Also, it is essential to pay attention to the components of such freedom including the information as a subject, public institutes as the obliged, and the holders of the right to access to information, so that the access to information is facilitated and fulfilled. The results obtained from the analysis of interviews showed that exceptions are not specified carefully in the context of the law. The exceptions are general and are in service of the executors. Combination of the public commission is from the ministries and organizations, which shall be responsible against people. There is no careful and serious sanction on the cases of violating freedom of information. Also, the relevant commission is not sufficiently powerful to fulfill the regulations and necessity of disclosure. No period is considered for the exceptions, and there is no certain definition available for the classified documents. Chapter four 
of the said law belongs to exceptions of access to information. Public secrets, protection of privacy, protection of health and commercial information, and national security are mentioned among these exceptions. In terms of the access conditions such as filtering (which was existed in the initial version and was deleted in the process of approval), the conditions shall be added with a comprehensive definition. In this law, the concept of freedom of information and the right of citizens to have access to information of public institutes are mixed. Also, it has happened in terms of access to information as an obligation of the government. The note $n$ article 5 is ambiguous: firstly, the information guaranteeing the determination of right and obligation for people is one of the characteristics of law, the dissemination of which is required. Secondly, the deadline of information delivery is not determined, which was not required, and shall not be dependent on the demand of the citizens. The affiliated institutes are not mentioned explicitly, and dependence on the government shall be specified. Besides, the legislator has referred to public institutes, and private institutes are neglected. The term "freedom of general information" is ambiguous in public and private institutes. The law has regarded personal information as individual information and has referred to examples to define that, which shall be amended.

The Law on Dissemination and Free Access to Information in Iran enables Iranian citizens to have access to information of public, general, and private institutes under complicated conditions mentioned in this study. The process can provide the principle of transparency of the affairs of the public sector and other institutes. However, there are fundamental problems in this field in the said law, and as is evident in the results of this study. The fulfillment of this law encounters abundant challenges in different fields, especially in legal terms, because of the current situation of Iran and the self-censorship culture; lack of transparency in different organizations on the dissemination of the information; unawareness of managers of secret information, and their expiration time; lack of required legal background in this field; lack of comprehensive bills; unawareness of people of their rights, and lack of democratic origins to such regulations. The law shall be revised, amended, and completed. Hence, the suggestions to amend the law in the legal field are:

Three bills of freedom of expression, privacy, and classification of public information by the state shall be submitted as prerequisite regulations to the parliament and approved for revision and better enforcement of the law. The system of exceptions in the rights of the citizen to have access to information is one of the most underlying sections of regulations on freedom of information. However, a lack of careful explanation of the restrictions has caused a lack of efficient sanctions in the field of freedom of information. Titles such as national security or public security are ambiguous titles. Some state institutes like the judiciary explain the concepts sometimes based on wide extended interpretations. They also prefer sometimes personal opinion and interest to the public interest.

A bill shall be submitted to Islamic Parliament (Majlis) by the cabinet based on amendment and completion of the said law.

The title of chapter 3 of the Law on Dissemination and Free Access to Information is transparency. According to the provisions of this chapter, the public institutes shall disseminate general information annually in addition to that information asked by the citizens to disseminate. Although the title of this chapter says that the public institutes shall make transparency on the decisions and measures, access to the information is dependent on paying through an application. However, it seems that the promotion of transparency in society needs regular dissemination of information by the public governments so that citizens can study the information for free. The necessity of paying for this purpose can be a barrier to transparency and is against the general purposes of this chapter of law.

Dissemination and Free access to Information need amendments. In absence of an explicit law, freedom of information can't be realized in Iran. As the use of social networks (Telegram and Twitter) is increased over the years, filtering the media and networks can violate the freedom of information and right to have free access to information.

The commission on dissemination and free access to information can be the driving motor of this law, the powers, and obligations of which shall be cleared. Also, one of the objections to this law is the lack of firm sanctions on different organizations. 
One of the serious weaknesses is the combination of commission on dissemination and free access to information. It would be better to establish an independent office (a subset of the presidency) with deployed and expert members (just like international samples).

Besides, by providing open political space for media and right to demand people by the government and organizations such as IRIB, new oxygen should be injected. By using the potential of the media and training people and managers at different social and political levels, they should become familiar with their rights and obligations.

In the end, it is hoped that the law can open new gates to promote the culture of transparency and democracy, and the secrecy culture can be replaced by that.

\section{References}

Asadi, Abbas. (2012). The Role of Investigative Journalism in Promoting Social Welfare, Journal of Culture and Media, No. 2.

Banisar, David. (2002). Freedom of Information and Access to Government Records Around the World. Viewed on: http: //www. privacyinternational.org

Corbin, j. \& Strauss, A. (1990). Basics of Qualitative Research: Techniques and Procedures for Developing Grounded Theory, London: Sage Publication, Inc.

Ghaderi, Behruz. (2010). Freedom of access to information and its impact on public oversight in public institutions, M.Sc. Thesis, Faculty of Law and Political Science, Allameh Tabatabai University.

Hashemi, Mohammad. (2012). Political Rights and Freedoms, Tehran: Mizan Publishing.

Hoshidari Farahani, Fatemeh. (2015). Explaining the Contexts of Implementing the Law on Dissemination and Free Access to Information in Iran, M.Sc. Thesis, Faculty of Management and Economics, Tarbiat Modares University.

Mohseni, Farid. (2005). Intersection of Privacy and Freedom of Information in Iranian Law, Quarterly Journal of Legal Perspectives, No. 36-37.

Motamednejad, Kazem. (2004). E-Communications and the Right to Freedom of Expression, Retrieved from Bashgah Andisheh website on June 6, 2016, at www.bashgah.net

Naderi, Amir Hossein. (2011). The right of free access to public information and documents in the Iranian legal system, M.Sc. Thesis, Faculty of Humanities, Tarbiat Modares University.

Rezayan Ghiyebashi, Ahad and Bayati, Leila. (2018). Scenarios of the presence and activity of the IRIB in cyberspace on the horizon of 2028 (Case study: Chaharmahal and Bakhtiari province broadcasting), Communication Research Quarterly, Volume 25, Number 4, pp. 9-39.

Sedghi, Abdullah. (2013). Evaluation of the Law on Dissemination and Free Access to Information in Iran in the Light of the Principles of Freedom of Information, M.Sc. Thesis, Allameh Tabatabai University.

*This article is derived from the Ph.D. thesis in the field of Communication Sciences from the Islamic Azad University of Ardabil branch. 